\title{
The influence of aggregate size fraction and horizon position on microbial community composition
}

\author{
Aaron Fox ${ }^{\mathrm{a}, \mathrm{b}, *}$, Israel Ikoyi ${ }^{\mathrm{b}}$, Gemma Torres-Sallan ${ }^{\mathrm{a}}$, Gary Lanigan ${ }^{\mathrm{a}}$, Achim Schmalenberger ${ }^{\mathrm{b}}$, \\ Steve Wakelin ${ }^{\mathrm{c}, \mathrm{e}}$, Rachel Creamer ${ }^{\mathrm{d}}$

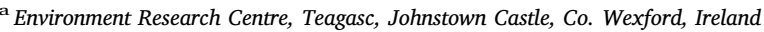 \\ ${ }^{\mathrm{b}}$ University of Limerick, School of Natural Sciences, Department of Biological Sciences, Limerick, Ireland \\ ${ }^{\mathrm{c}}$ Lincoln Science Centre, AgResearch Ltd., Christchurch, New Zealand \\ ${ }^{\mathrm{d}}$ Wageningen University, Soil Biology and Biological Soil Quality, Wageningen, The Netherlands \\ e Scion Research, Forestry Drive, PO Box 29237, Christchurch 8440, New Zealand
}

\section{A R T I C L E I N F O}

\section{Keywords:}

Bacteria

Fungi

Aggregate sized fraction

Horizon position

Community profiling

Next generation sequencing

\begin{abstract}
A B S T R A C T
The influence of horizon position and aggregate size on bacterial and fungal community composition was determined. From nine sites, soils were collected from the top three horizon positions (H1, H2 and H3). Physical fractionation separated samples into large macroaggregate ( $\mathrm{LM},>2000 \mu \mathrm{m}$ ), macroaggregate (MAC, $>250 \mu \mathrm{m}$ ), microaggregate (MIC, $<250 \mu \mathrm{m}$ ), and silt and clay (SC, $53 \mu \mathrm{m}$ ) fractions. In all samples, the structure of the bacterial and fungal community composition was assessed via restriction fragment length polymorphism (T-RFLP), and for the four aggregate sizes from the top two horizons positions an in-depth analysis of the bacterial community was conducted using next generation sequencing (NGS). Bacterial and fungal communities both differed between aggregate-sizes. Changes in the composition of the bacterial and fungal communities also occurred among horizon positions, with a significant interaction between aggregate size and horizon position evident for the bacterial community. Using NGS, it was shown that aggregate-size had a significant effect on the bacterial community in both horizon positions at both the phyla and family taxonomic levels. MAC and MIC significantly differed in the \% relative abundance of bacterial groups, potentially indicating differing predation pressures. These results indicate that both horizon position and aggregate size support distinct microbial communities. Understanding these parameters is critical in our comprehension of the patterns of microbial diversity in soil.
\end{abstract}

\section{Introduction}

The majority of our understanding of soil microbial ecology has concentrated on bulk soil samples. While these studies have provided profound insights into the diversity and functioning of soil ecosystems (Bowles et al., 2014; Thomson et al., 2015; Wakelin et al., 2008), they have not accounted for the inherent heterogeneity of microbial diversity seen over small spatial scales (Mummey et al., 2006; Vos et al., 2013). Investigations of soil microbiology, at the appropriate spatial scale, are considered to be important in providing a deeper understanding into the functioning of soil ecosystems (O'Brien et al., 2016; Raynaud and Nunan, 2014; Vos et al., 2013).

The structure of soil is made up of an arrangement of tortuous physical networks which determine the flow of substrates and solutes in space and over time. This provides a diverse range of physicochemical niches characterized by variation in nutrient quantity and quality, redox conditions, variation in water filled pore space, and pore size classes available for microbial habitation (Mummey and Stahl, 2004). Much of the variation in these properties can be partitioned among the distinct aggregate size fractions present in soil, as these vary in physical, chemical, and structural characteristics (Ranjard et al., 2000). Aggregates are secondary structures formed through the interactions of mineral particles as well as organic and inorganic substances (Bronick and Lal, 2005; Tisdall and Oades, 1982). They are grouped according to size, with large macroaggregates being considered $>2 \mathrm{~mm}$ in size macroaggregates generally being considered over $250 \mu \mathrm{m}$ in size while microaggregates are less than $250 \mu \mathrm{m}$ in size (Bronick and Lal, 2005). Additionally, the stability, distribution, and microarchitecture within and between soil aggregates is linked to the composition and function of the microbiome (Mikha and Rice, 2004).

The two largest aggregate size fractions are formed through temporary associations of minerals, particulate organic matter, and large-

\footnotetext{
* Corresponding author at: Agroscope, Forage Production and Grassland Systems, Zürich, Switzerland.

E-mail address: aaron.fox@agroscope.admin.ch (A. Fox).
} 
or micro-aggregates. This binding is largely mediated through the enmeshment of fungal hyphae and plant roots (Mummey and Stahl, 2004; Rillig and Mummey, 2006). Microaggregates (MIC) are formed through the binding of bacterial polysaccharides with clay particles, organomineral complexes, and polyvalent metals (Six et al., 2004), and are largely formed within macroaggregate structures. These aggregate size fractions represent distinct microhabitats for microbial colonization and substrate utilization. The large macroaggregate (LM) and macroaggregate (MAC) fractions are enriched with labile carbon (C) and nitrogen $(\mathrm{N})$, predominantly of plant origin and fungal origin (Marx et al., 2005). Microaggregates (MIC) are characterized by having lower concentrations of labile $\mathrm{C}$ and increased amounts of biochemically recalcitrant C (i.e. compounds with a higher C:N ratio), and physicallyprotected $\mathrm{C}$, i.e., $\mathrm{C}$ that is associated with soil organic matter and not free particular organic matter and which microbial decomposers and their enzymes have a greater difficulty gaining access to (Elliott, 1986; Kravchenko et al., 2015). In addition, the interior of microaggregates have been described as inherently oligotrophic, with low nutrient and $\mathrm{O}_{2}$ availability resulting in reduced microbial activity (Mummey and Stahl, 2004). The silt and clay fraction (SC) has relatively stable $\mathrm{C}$ and $\mathrm{N}$ and high levels of microbial biomass have been reported within them (Elliott, 1986; Sessitsch et al., 2001; vanGestel et al., 1996). Microbial acquisition of substrate is compounded by the sorption of extracellular enzymes to clay particles in the SC, with this process likely being responsible for the distinct microbial activities and community structures reported (Allison and Jastrow, 2006; Mueller, 2015; Sessitsch et al., 2001).

Understanding the interplay between aggregate size and the soil microbiome is an important consideration for achieving sustainability in our agroecosystems, particularly the retention of soil organic carbon (SOC). Occlusion within aggregates is a well-known mechanism of SOC preservation, and the patterns of microbial community structure and activity within aggregates may be key to understanding this function (Six et al., 1998; Torres-Sallan et al., 2017). It will also have important implications for the preservation of soil biodiversity and the management of microbial communities for bio-control and plant disease suppression (Grundmann, 2004).

The experimental aim of this study was to elucidate the influence of both aggregate size fraction and horizon position on the patterns of both bacterial and fungal community structures. The working hypothesis being that the two largest aggregate sizes (LM and MAC) would significantly differ from the two smaller aggregate sizes (MIC and SC) due to changing physicochemical conditions (i.e., increased microporosity). The study also hypothesised that different horizon positions would also significantly impact microbial community compositions with the aggregates sizes, as soil physicochemical conditions will also vary by horizon. Firstly, bacterial and fungal community composition from the top three horizon positions was determined using communitylevel fingerprinting. Secondly, the study narrowed its focus to ascertain how specific bacterial groups were influenced by aggregate size in the top two horizons using next generation sequencing (NGS).

\section{Materials and methods}

\subsection{Soil collection}

Soil samples were collected from nine (predominantly grassland soils used in livestock production) sites in the North-West of the Republic of Ireland as part of the Irish Soil Information System (Irish SIS) soil survey (Creamer et al., 2014) (project soils collected were: RPM79br01, RPM68br01, RPM66br01, RPR49br01, RPM45br01, RPM85br01, RPG62Br02, RPG52BR01 and RPG63br01). At each sampling site a $1 \mathrm{~m}^{2} \times 1 \mathrm{~m}$ deep pit was dug. After the pit face was cleaned of loose soil, the profile was designated into distinct horizons following the UN food and agricultural organizations (FAO) guidelines for soil description (FAO, 2006) and classified using the World Reference Base system (WRB, 2006). The top three horizon positions were sampled (the top horizon position from each site is henceforth collectively referred to as $\mathrm{H} 1$, the second horizon position as $\mathrm{H} 2$ and the third horizon position as H3) to a depth of no more than $1 \mathrm{~m}$, resulting in 26 samples. No samples could be gathered from the third horizon position of RPM66Br01 due to the large amount of stony material present. Details on soil type, drainage, horizon types and depths, textural class as well as sand, silt and clay proportions are provided in the supplementary materials (SM1 and SM2).

Approximately $300 \mathrm{~g}$ of soil was collected from each of the described horizons, across the nine soil profiles pits sampled. Samples were collected using aseptic technique as far as was practicable under field conditions i.e., use of 70\% ethanol and sterilized water to sanitise equipment between samplings. Furthermore, samples were collected from the lowest horizon up to prevent soil from the upper horizons contaminating the lower horizons. Soil samples were collected into sterile twist-seal bags and kept at $4{ }^{\circ} \mathrm{C}$ in a cool box for transportation. Soils were not frozen at this stage to prevent damage to the constituent aggregate structures. Once back in the lab (within $48 \mathrm{~h}$ of collection), samples were homogenized and sieved $(<8 \mathrm{~mm})$.

\subsection{Soil aggregate isolation}

The aggregate isolation procedure was based on a technique described previously (Six et al., 1998). Briefly, soil samples were dried at $40{ }^{\circ} \mathrm{C}$ for 1 week. Wet-sieving, with the retention of the material on the sieve as an 'operationally defined fraction' and re-sieving of the soil which passed through the sieve was conducted. This process was sequential through $2 \mathrm{~mm}, 250 \mu \mathrm{m}$, and $53 \mu \mathrm{m}$ sieves which provided the large macroaggregate (LM), macroaggregate (MAC), and microaggregate (MIC) fractions. Material $<53 \mu \mathrm{m}$ was deemed the silt and clay fraction (SC). The LM, MAC, and MIC fractions were collected into $100 \mathrm{ml}$ containers. Any material, e.g., dead plant material, which floated in the water during the isolation of the LM aggregate size was removed by hand as this was not considered soil organic matter. The SC fraction was collected along with the excess water from the procedure into dual $500 \mathrm{ml}$ containers. All material was dried at $50{ }^{\circ} \mathrm{C}$ for 1 week, after which time the samples were weighed and the \% proportion of each aggregate size fraction was corrected relative to the bulk soil (Six et al., 1998). To test the replicability of the fractionation procedure, every 10th sample was repeated. Samples were homogenized via mixing and a subsample (approximately half of the material obtained during fractionation) was immediately stored at $-80^{\circ} \mathrm{C}$ for later molecular work. All laboratory materials pertaining to the fractionation procedure were thoroughly washed in ethanol $(70 \% \mathrm{v} / \mathrm{v})$ between each sample to disinfect equipment. A total number of 104 aggregate size fraction samples were obtained.

\subsection{Aggregate course/fine sand determination}

Stones $>2 \mathrm{~mm}$ were removed from LM and the associated mass subtracted. The amount of coarse and fine sand contained within the MAC and MIC fraction was also calculated as it may distort the true proportion of these aggregates within the bulk soil. Approximately $20 \mathrm{~g}$ of soil was placed into a $250 \mathrm{ml}$ Erlenmeyer flask. To remove organic matter, $6 \%(\mathrm{v} / \mathrm{v})$ hydrogen peroxide $\left(\mathrm{H}_{2} \mathrm{O}_{2}\right)$ was added to cover the soil. The solution was boiled at $100{ }^{\circ} \mathrm{C}$ with additional $\mathrm{H}_{2} \mathrm{O}_{2}$ being added to replace that lost by evaporation. Organic matter was deemed to be completely removed when the bubbles formed during the process turned clear. Any excess $\mathrm{H}_{2} \mathrm{O}_{2}$ was decomposed through the addition of $25 \mathrm{ml}$ of $10 \%$ ammonium hydroxide. Contents of the flasks were washed through a series of sieves ( $250 \mu \mathrm{m}$ sieve on top and $53 \mu \mathrm{m}$ sieve on the bottom) to collect the coarse ( $>250 \mu \mathrm{m}$ ) and fine ( $>53 \mu \mathrm{m}$ ) sands. Once dried, these were weighed and the proportion of coarse and fine sand removed from the MAC and MIC fractions, respectively (Massey et al., 2014). 
Edaphic and environmental parameters of the bulk soil from each soil sample were collected as part of the Irish SIS survey following the Irish SIS laboratory protocols (Massey et al., 2014). Parameters measured were total carbon $(\mathrm{C})$, total nitrogen $(\mathrm{N})$, cation exchange capacity (CEC), $\mathrm{pH}\left(\mathrm{H}_{2} \mathrm{O}\right)$ as well as extractable phosphorus (P), potassium $(\mathrm{K})$, magnesium $(\mathrm{Mg})$, and calcium $(\mathrm{Ca})$. Soil textural analysis was also undertaken. These parameters were not measured on the aggregate scale as it was not possible to obtain the amount of soil necessary to conduct all these analyses.

\subsection{DNA extraction}

DNA was extracted from each of the constituent aggregate size fractions $(0.25 \mathrm{~g})$ using the Powerlyzer version of the Powersoil DNA isolation kit (MO BIO laboratories, Cupertino, CA). The protocol was undertaken as described in the manufacturer's instructions. The physical disruption (bead beating) was undertaken on a Fast-Prep ${ }^{\mathrm{TM}}-24$ instrument (MP Biomedicals, Santa Ana, CA) at a speed of 4 for $45 \mathrm{~s}$. DNA extracts were quantified spectrophotometrically using a Nano-drop ND1000 (Thermo Scientific, Waltham, MA). Extracts were then diluted with sterile $\mathrm{ddH}_{2} \mathrm{O}$ to a concentration of $10 \mathrm{ng} / \mu \mathrm{l}$ for subsequent fingerprinting analysis and $5 \mathrm{ng} / \mu \mathrm{l}$ for NGS.

\subsection{PCR amplification of soil bacterial $16 S$ and fungal ITS community}

The fluorescently labelled universal primer set $27 \mathrm{~F}\left(5^{\prime}-/\right.$ 5ATTO565N/AGA GTT TGA TCM TGG CTC AG'3) and 1492R (5'-/ 5ATTO565N/TAC GGY TAC CTT GTT ACG ACTT'3) (Lane, 1991) were used to amplify the bacterial 16S rRNA gene. PCR was conducted in final volumes of $25 \mu$, containing $1 \times$ Dreamtaq buffer, $1 \mathrm{M}$ betaine, $0.2 \mathrm{mM}$ dNTP-Mix, $0.4 \mathrm{pmol} / \mu \mathrm{l}$ of both the forward and reverse primer, and 0.5 U Dreamtaq polymerase (Thermo Scientific, Waltham, MA). Each reaction received $1 \mu \mathrm{l}$ of template DNA at $10 \mathrm{ng} / \mu \mathrm{l}$. PCR cycling conditions consisted of an initial denaturation step of $94^{\circ} \mathrm{C}$ for $4 \mathrm{~min}$, followed by 35 cycles of $94^{\circ} \mathrm{C}$ denaturation for $45 \mathrm{~s}, 50^{\circ} \mathrm{C}$ annealing for $45 \mathrm{~s}$, and $72^{\circ} \mathrm{C}$ extension for $2 \mathrm{~min}$, and then followed by a final extension at $72{ }^{\circ} \mathrm{C}$ for $5 \mathrm{~min}$.

The internal transcribed spacer (ITS) region of the rRNA gene region was used as a marker gene for characterisation of the soil fungal community. Fungal-specific PCR was undertaken using a nested approach. Non-fluorescently labelled fungal specific primers ITS-1F (5'CTT GGT CAT TTA GAG GAA GTA A-3') (Gardes and Bruns, 1993) and ITS-4 (5' TCC TCC GCT TAT TGA TAT GC-3') (White et al., 1990) were used in the initial amplification reaction. PCR mixtures were otherwise as described for bacterial amplification. Amplification conditions consisted of an initial denaturation step of $94^{\circ} \mathrm{C}$ for $4 \mathrm{~min}$, followed by 40 cycles of denaturation at $94^{\circ} \mathrm{C}$ for $45 \mathrm{~s}$, annealing at $50{ }^{\circ} \mathrm{C}$ for $45 \mathrm{~s}$, and extension at $72{ }^{\circ} \mathrm{C}$ for $1 \mathrm{~min}$, with a final extension step of $72{ }^{\circ} \mathrm{C}$ for $10 \mathrm{~min}$. A $1 \mu \mathrm{l}$ aliquot of a $1: 10$ dilution of this first amplification was used as template DNA in the second PCR, using the primers (labelled with the same fluorophores as the bacterial primers) and amplification conditions as described before.

\subsection{Terminal restriction fragment length polymorphism (T-RFLP)}

T-RFLP of bacterial 16S rRNA was conducted on $200 \mathrm{ng}$ of purified PCR amplicons (GenElute PCR clean-up kit, Sigma Aldrich). These were subjected to a double restriction digestion using AluI and HhaI at $37^{\circ} \mathrm{C}$ for $8 \mathrm{~h}$ (Fox et al., 2017; Penny et al., 2010). A sequential restriction digest was done on $200 \mathrm{ng}$ of purified fungal ITS community PCR amplicon with an initial restriction reaction using MaeII at $65^{\circ} \mathrm{C}$ for $8 \mathrm{~h}$ (Alvarado and Manjón, 2009; Fox et al., 2017). Reactions were allowed to cool at $4^{\circ} \mathrm{C}$ overnight, whereupon a restriction digest was performed with Hhal for a further $8 \mathrm{~h}$ at $37^{\circ} \mathrm{C}$. All restriction digest reactions contained $5 \mathrm{U}$ of enzyme per reaction in a $10 \times$ FastDigest buffer (all Thermo Scientific, Waltham, MA).
All restriction digests were 1:10 diluted and sent for fragment size and intensity analysis at MRC PPU DNA sequencing and Services (University of Dundee, Scotland, UK). Fragment sizes were determined on an applied Biosystems 3730 XL DNA analyser, using the LIZ500 size marker. Resultant electrophoretograms were imported into Genemapper (version 3.7, ABI, UK), and terminal restriction fragments (TRFs) binned with a $2 \mathrm{bp}$ interval. T-RFs between 80 and 500 bp were included in the analysis and a presence/absence matrix was generated.

\subsection{Next generation sequencing}

The bacterial 16S rRNA V4 gene region was amplified using the universal primer pair $515 \mathrm{~F}$ and $806 \mathrm{rBC}$. PCR reactions were $25 \mu \mathrm{l}$ with $0.4 \mu \mathrm{M}$ of each primer, $0.2 \mu \mathrm{M}$ dNTPs, $1 \times$ PCR buffer with $1.5 \mathrm{mM}$ $\mathrm{MgCl}_{2}$, and $0.5 \mathrm{U}$ of TaKaRa Ex Taq polymerase. The PCR amplification conditions were conducted with an initial denaturation at $94^{\circ} \mathrm{C}$ for 3 min followed by 35 cycles of $94^{\circ} \mathrm{C}(45 \mathrm{~s}), 50^{\circ} \mathrm{C}$ annealing $(60 \mathrm{~s})$ and $72{ }^{\circ} \mathrm{C}$ extension ( $90 \mathrm{~s}$ ) with a final extension step of $72{ }^{\circ} \mathrm{C}$ for $10 \mathrm{~min}$. The PCRs were multiplexed, such that each DNA sample was amplified with a unique 12-mer barcoded $806 \mathrm{rBC}$ primer (GoLay barcodes) (Apprill et al., 2015). Individual PCR products for all samples were quantified using the high sensitivity Quant-iT PicoGreen spectroscopy method (Invitrogen), then equimolar amounts of each PCR were pooled into a single sample. The resultant mixed PCR product was purified using the GeneElute PCR purification kit (Sigma-Aldrich, St. Louis, MO) and quantified again as above. The amplicon mix was sequenced using $2 \times 250$ PE sequencing on an Illumina Miseq NGS platform (Illumina, San Diego, CA) at the University of Auckland. While it was attempted to obtain fungal ITS amplicons for NGS analysis, sufficient amplification from these samples could not be obtained.

The generated reads were processed, joined and analysed using the mothur (v.1.36.0) (Schloss et al., 2009) program following the commands described in the Miseq SOP (detailed: https://www.mothur.org/ wiki/MiSeq_SOP). Sequences were matched and aligned with chimeras and mismatched sequences removed from the data-set. Rarefaction curves were also undertaken to deduce the sequencing depth covered. Mothur was used to assign taxonomy to the sequences against the SILVA (release 102) reference database. Taxonomic information at the phylum and family taxonomic levels were consolidated from the mothur output files.

\subsection{Statistics}

\subsubsection{Effect of horizon position on measured environmental variables and} $\%$ proportion of aggregate size fractions to bulk soil

The nine measured environmental variables from the collected bulk soil were imported into the statistical software program $\mathrm{R}$ (version: 3.2.2) and the data was then checked for normal distribution using the Shapiro-Wilk test and for homogeneity of variance using Levene's test. The variables which passed this test (Mg, $\mathrm{pH}$ and $\mathrm{CEC}$ ) were subjected to a one-way ANOVA (with Tukey HSD post hoc test) to test for the influence of horizon position. The remaining variables which did not display normal distribution were $\log _{10}$ transformed. A non-parametric test (one way test, followed by a pairwise $t$-test) was conducted on the variables which still did not show a normal distribution following the transformation (total $\mathrm{N}$ and $\mathrm{K}$ ). The same tests were also used to determine the effect of horizon position on the \% proportion each aggregate size fraction contributed to the bulk soil.

\subsubsection{Microbial community composition and richness}

The presence/absence matrix of the T-RFLP electrophoretograms from each aggregate size fraction was imported into PRIMER-E (Version 7, Plymouth, UK) and a Bray-Curtis resemblance matrix was constructed. A Bray-Curtis distance was chosen as it has broad suitability for representing distances (similarities) in biological data sets (Clarke and Warwock, 2001). Permutational multivariate analysis of variance 
(PERMANOVA) (Monte Carlo, 9999 permutations) was used to test for differences in T-RFLP profiles between aggregate size fractions and horizon position. Similarities between samples were displayed using multi-dimensional scaling (MDS), with bootstrapping to determine group variance and averages (300 per group, bootstrap region 95\%).

As with the T-RFLP data, the relative \% abundance of bacterial OTUs obtained from the NGS were imported into PRIMER-E, standardized to the total number of individuals, $\log (X+1)$ transformed, and a Bray-Curtis resemblance matrix constructed. A PERMANOVA analysis was then used to determine the influence of aggregate size and horizon position. Statistical differences in the relative \% abundance of individual phyla/families between different aggregate size fractions and horizon positions were determined via ANOVA analysis in the R statistical software as described previously. The Margelef's richness (d), Shannon-Wiener diversity index $\left(\mathrm{H}^{\prime}\right)$, and Pielou's evenness index $\left(\mathrm{J}^{\prime}\right)$ were calculated from the NGS data for each sample using the DIVERSE function in PRIMER-E, the influence of both aggregate size fraction and horizon position on these parameters was determined by a one-way ANOVA in the $\mathrm{R}$ statistical software package as has been described previously.

\section{Results}

\subsection{Chemical and physical characteristics of the bulk soil with depth}

There was a significant main effect of horizon position on the concentrations of $\mathrm{Mg}(\mathrm{P}=0.017)$, total $\mathrm{C}(\mathrm{P}=0.04)$, total $\mathrm{N}(\mathrm{P}=0.028)$, $\mathrm{P}(\mathrm{P}<0.001)$, and $\mathrm{pH}(\mathrm{P}=0.032)$. Pairwise tests also revealed that the concentrations of $\mathrm{Mg}$ was significantly reduced in $\mathrm{H} 3(0.37 \mathrm{mg} / \mathrm{kg})$ compared with $\mathrm{H} 1(1.1 \mathrm{mg} / \mathrm{kg} ; \mathrm{P}=0.018)$. The $\mathrm{pH}$ value was also significantly higher in $\mathrm{H} 3$ and $\mathrm{H} 2(\mathrm{pH} 6.99$ and 5.99 respectively) compared with $\mathrm{H} 1$ (pH 5.55; both $\mathrm{P}<0.001$ ).

There was a significant effect of horizon position on the \% proportion that the LM, MIC and SC fraction contributed to the bulk soil. The \% proportion that the LM fraction contributed was significantly lower in $\mathrm{H} 3$ than it had been in either $\mathrm{H} 2$ or $\mathrm{H} 1$ and additionally was also lower in $\mathrm{H} 2$ than it had been in $\mathrm{H} 1$. The exact opposite was seen with the MIC fraction which increased its \% proportion to the bulk soil through each of the horizon positions through H1-H3 (P $<0.05)$. The SC fraction also contributed a higher \% proportion to the bulk soil in $\mathrm{H} 2$ and $\mathrm{H} 3$ than it had in $\mathrm{H} 1$ ( $\mathrm{P}=0.043$ and $\mathrm{P}=0.010$ respectively). There was no significant effect of horizon position on the \% proportion of the MAC fraction. Information pertaining to the physicochemical properties of the soils in this study can be found in the supplementary materials (SM1-4).

\subsection{Bacterial community structure within aggregate fractions}

Bacterial community composition differed significantly among aggregate size classes when all horizon positions were considered as a whole ( $\mathrm{P}<0.0001$ ), with communities in the SC fraction being significantly different from LM, MAC, and MIC (all $\mathrm{P}<0.0001$ ). Communities within LM, MAC, and MIC fractions were similar (Fig. 1; top). A significant effect of aggregate-size was also observed on 16S T$\mathrm{RF}$ richness $(\mathrm{P}<0.0001)$, with the SC fraction having a significantly higher richness than the LM $(\mathrm{P}=0.007)$, MAC $(\mathrm{P}<0.001)$, and MIC $(\mathrm{P}<0.001)$ fractions (supplementary materials SM 5).

The bacterial community composition of aggregates was also significantly influenced by horizon position $(\mathrm{P}<0.0002)$, with $\mathrm{H} 1$ being significantly different from both H2 $(\mathrm{P}<0.01)$ and H3 $(\mathrm{P}<0.0001)$, while $\mathrm{H} 2$ and $\mathrm{H} 3$ were similar $(\mathrm{P}=0.17$ ) (Fig. 2; top). A significant interaction between horizon position and aggregate size fraction was also observed $(P<0.007)$, indicating that the bacterial community composition within aggregates were responding to the inherent changes in physiochemical parameters of each horizon position. Partition of variances associated with horizon position and aggregate size found that aggregate size fraction explained the highest amount of variation in bacterial community composition ( $\mathrm{VCV}$ : 19.09), followed horizon position ( $\sqrt{ } \mathrm{CV}$ : 11.7 ). $69.21 \%$ of the variation remained unexplained by the treatments tested (summarized in Table 1).

On the individual horizon position level, there was a significant aggregate-size effect observed in both $\mathrm{H} 1$ and $\mathrm{H} 2$ on bacterial $(\mathrm{P}<0.0001$ and $\mathrm{P}<0.008$, respectively, Table 2$)$ community composition. In each case this was due to the SC fraction being significantly different from each of the larger aggregate sizes (summarized in Table 2). There was also a significant aggregate size effect on 16S T-RF richness for $\mathrm{H} 1$ and $\mathrm{H} 2$ (both $\mathrm{P}<0.01$ ), with the SC fraction being significantly richer in bacterial $16 \mathrm{~S}$ T-RFs than the MAC and MIC fraction sizes in $\mathrm{H} 1$ and all three larger fraction sizes in H2 (supplementary materials SM 6). There was no overall effect of aggregate size on bacterial community structure in H3 (Table 2).

\subsection{Fungal community structure within aggregate fractions}

Aggregate size also significantly influenced fungal community composition $(\mathrm{P}<0.0001)$ when all horizon positions were considered as a whole, with again the SC fraction being significantly different from the larger aggregate-sizes (all $\mathrm{P}<0.0001$, Fig. 1; bottom). The fungal community composition of aggregates was also affected by horizon position $(\mathrm{P}<0.0001)$ with $\mathrm{H} 1$ being significantly different from $\mathrm{H} 2$ $(\mathrm{P}<0.03)$ and H3 $(\mathrm{P}<0.03)$. Additionally, H2 and H3 were significantly distinct from each other $(\mathrm{P}<0.048$, Fig. 2 ; bottom). Analysis of the variation apportioned to horizon position and aggregate size indicated that aggregate size explained the greatest amount of the variation seen in the fungal community composition ( $V C V: 17.82)$ followed by horizon position ( $\mathrm{V} C \mathrm{~V}: 16.25) .65 .93 \%$ of the variation remained unexplained by the parameters tested (summarized in Table 1). On the individual horizon position level, there was a significant aggregate size effect observed in both $\mathrm{H} 1$ and $\mathrm{H} 2$ on fungal $(\mathrm{P}<0.0001$ and $\mathrm{P}<0.03$, respectively) community composition, with the SC fraction being significantly different from each of the larger aggregate sizes in both cases (Table 2). A significant overall fraction effect $(\mathrm{P}=0.04)$ was also observed in the case of the fungal community composition in H3, with SC differing from MIC $(P=0.03)$ (Table 2).

\subsection{Next generation sequencing}

\subsubsection{Bacterial community structure as investigated by NGS}

There was a significant effect of aggregate size in the relative $\%$ abundance of bacterial phyla present in H1, with this change largely being due to the difference between the MAC and MIC aggregates sizes $(\mathrm{P}<0.001)$. Such compositional differences were also reflected in changes in the univariate diversity measures, with significantly greater diversity $\left(\mathrm{H}^{\prime}\right)$ and evenness $\left(\mathrm{J}^{\prime}\right)$ in the MAC fraction compared to MIC (Supplementary materials, SM 9). The most abundant phyla in these samples was the Firmicutes. These were significantly lower in relative abundance in the MAC fraction (42.27\%) compared to the MIC fraction $(80.54 \%)$. In contrast, the relative \% abundance of other major phyla, namely Acidobacteria, and Chlamydiae were all higher in the MAC than in the MIC fraction (Table 3).

In the $\mathrm{H} 2$ horizon position, there was also a significant effect of aggregate size at both the phyla and family levels $(\mathrm{P}<0.05)$. The MAC and SC fractions differed significantly in the relative $\%$ abundance of bacterial phyla present $(\mathrm{P}=0.036)$. The major phyla Acidobacteria, Actinobacteria, Bacteroidetes, Planctomycetes and Chlamydiae all had a significantly lower abundance in the MAC compared with the SC fraction (Table 3). At the family level, both $\mathrm{LM}$ and $\mathrm{SC}(\mathrm{P}=0.024$ and $\mathrm{P}=0.002$ respectively) were significantly different from MAC. No significant difference was seen in any diversity measure for either taxonomic level in H2 (supplementary materials SM 9). Tables of the \% relative abundance of major bacterial families (i.e, abundance greater than $0.01 \%$ is also provided in the supplementary materials (SM 7 and SM 8)). 

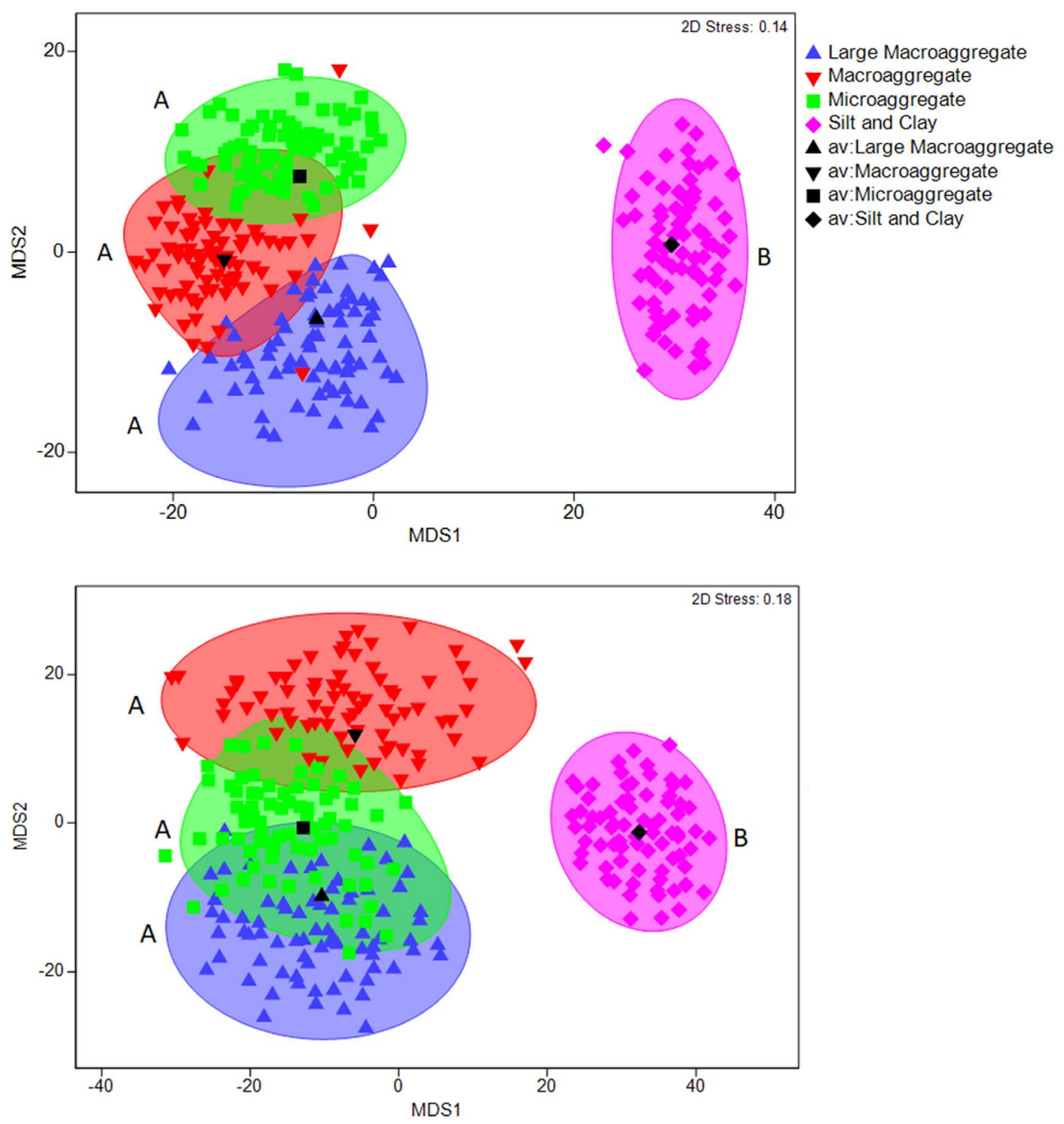

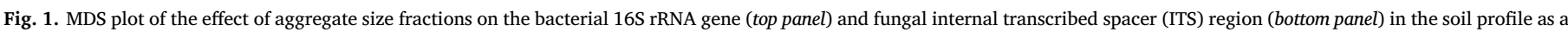

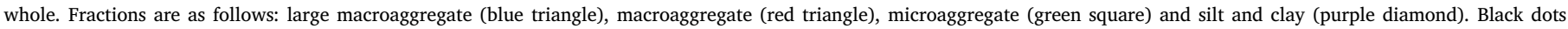

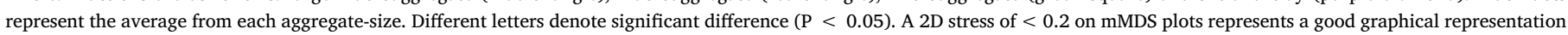
of the data in two dimensions. (For interpretation of the references to colour in this figure legend, the reader is referred to the web version of this article.)

3.4.2. The allocation of bacterial phyla and families between and within the various aggregate-sizes as determined by NGS

Of the 21 phyla reported in H1, 16 were shared among all the aggregate sizes. Only the SC fraction harboured phyla which were not found in other aggregates (Deferribacteres and Spirochaetes), while the candidate phyla BRC1 and OP11 were found within SC, LM and MAC with OD1 shared between SC and the MAC (SM 10). Of the 123 families reported in $\mathrm{H} 1,83$ were shared among all aggregates. Of the 40 families not shared among all fractions, only seven (Desulfuromonadaceae, Enterobacteriaceae, Granulosicoccaceae, Incertae_Sedis_XIV, Rickettsiaceae and unclassified group in the family Chromatiales found in MAC and Alcaligenaceae found in MIC) were not found in the SC fraction at all.

The SC fraction harboured eight unique families (Campylobacteraceae, Cryomorphaceae, Deferribacterales_incertae_sedis, Hydrogenophilaceae, Leptospiraceae, Methylophilaceae, Rikenellaceae and Spirochaetaceae), while sharing eleven with LM and MAC and eight solely with MAC. While only the Sporolactobacillaceae is shared with LM, MIC and SC five families (Caryophanaceae, Eubacteriaceae, GpI, Puniceicoccaceae,
Syntrophomonadaceae) were shared among SC, MIC and MAC (Fig. 3; top panel).

No phyla were unique to any one of the aggregate-sizes in H2, with 14 of the 17 phyla detected shared among all of them. Nitrospira and BRC1 were shared among SC and the MIC and LM fractions respectively, with WS3 being shared among all three (SM 10). A total of 106 families were detected in $\mathrm{H} 2,64$ of them were shared among all the aggregate sizes. Only eight of the remaining 42 families were not found in either solely in the SC or shared among the SC and the other aggregate sizes, five of these were found exclusively in MIC: Campylobacteraceae, Methylophilaceae, Moraxellaceae, Rhodobacteraceae, and an unclassified group in the family Rhodospirillales.

A total of seven bacterial families (Alcaligenaceae, Cytophagaceae, Nitrosomonadaceae, Pseudomonadaceae, Saprospiraceae, Verrucomicrobiaceae and an unclassified group in the Flavobacteriales family) were found exclusively in the SC fraction. An additional 14 families were shared between SC and MIC, with Desulfobulbaceae shared between SC and LM. A further four families (Caryophanaceae, Rhodocyclaceae, and 

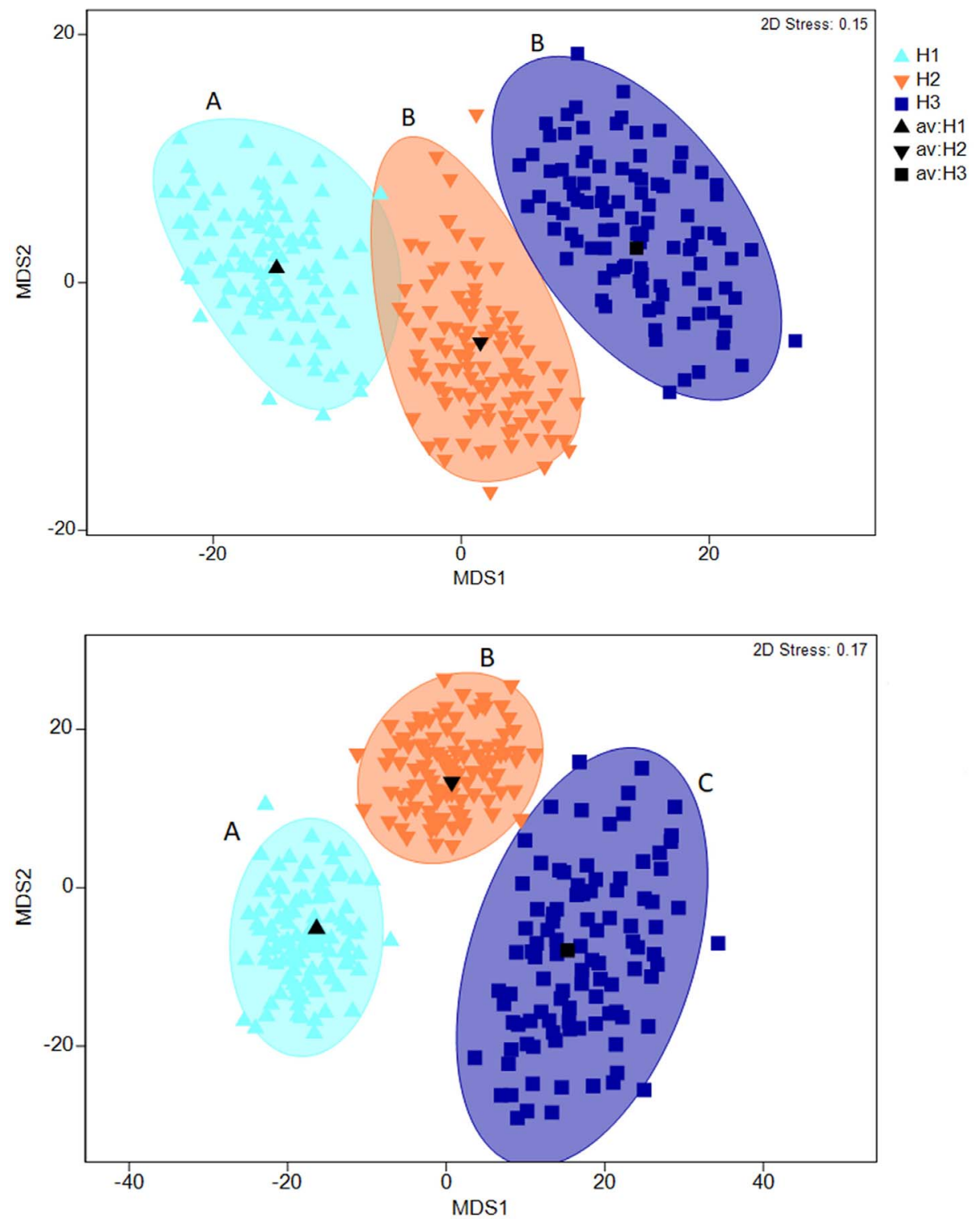

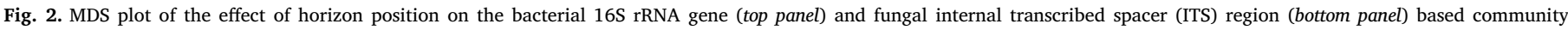

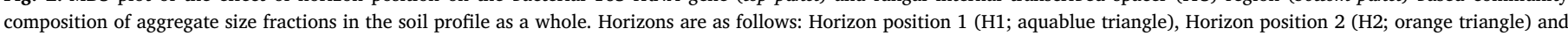

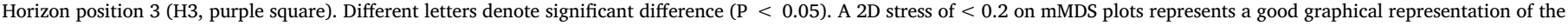
data in two dimensions. (For interpretation of the references to colour in this figure legend, the reader is referred to the web version of this article.)

unclassified groups in the Cyanobacteria and WS3 families) were found in all three aggregates (Fig. 3; bottom panel). All of the phyla and families which were not shared among all of the aggregate-sizes in both horizon positions had an average relative $\%$ abundance of below $0.1 \%$.

\subsubsection{Interaction between horizon position and aggregate size fraction}

Horizon position had a significant effect on bacterial OTU abundance of the aggregate size fractions at both taxonomic levels (phylum $\mathrm{P}=0.037$; family $\mathrm{P}=0.004$ ). Analysis of the variation in abundance at the family level apportioned to horizon position and aggregate size did indicate that horizon explain a greater amount of the variation $(\sqrt{ } \mathrm{CV}$ : 10.35) than did fraction ( $\mathrm{V} C \mathrm{~V}$ : 9.99 ), with $79.66 \%$ of variation not explained by the variables tested. There was a significant interaction between aggregate size and horizon position in terms of \% relative abundance of bacterial OTUs at both the phylum $(\mathrm{P}=0.004)$ and family levels $(\mathrm{P}=0.001)$.

Bacterial communities associated with the MAC fraction were most influenced by horizon position, with there being a significant change in the $\%$ relative abundance of bacterial OTUs in this fraction between horizon positions for both taxonomic levels, with a significant change in all phyla (over $0.01 \%$ abundance) with the exception of WS3, OP10 and Proteobacteria. Indeed, the MAC fraction in $\mathrm{H} 2$ did differ in bacterial \% relative abundance in both of the taxonomic levels from SC in both horizon positions. Furthermore, the MAC fraction from H1 differed from the MIC fraction in $\mathrm{H} 2$ in terms of abundance of OTUs (phyla: $\mathrm{P}=0.01$; family: $\mathrm{P}=0.009$ ). A summary of the pairwise tests in the abundance of bacterial OTUs between different aggregate sizes within horizons is provided in the supplementary materials (SM 11).

\section{Discussion}

A highly significant effect of aggregate size and horizon position was observed on bacterial and fungal community composition using both the T-RFLP fingerprinting technique and next-generation sequencing. Using T-RFLP, while an overall effect of aggregate-size was seen on community composition for both bacteria and fungi in the top two horizon positions, there was no such effect (as in the case for bacteria) or a greatly reduced effect (as with the fungi) in H3. With all horizon 
Table 1

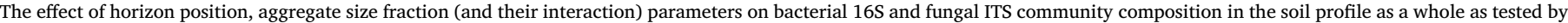
PERMANOVA analysis. Statistical significance $\mathrm{P}<0.05$

\begin{tabular}{|c|c|c|c|c|c|c|}
\hline \multirow[t]{2}{*}{ Community } & \multirow[t]{2}{*}{ Parameter } & \multicolumn{2}{|l|}{ Main effect } & \multirow[t]{2}{*}{$\sqrt{ } \mathrm{CV}$} & \multirow[t]{2}{*}{ Pairwise } & \multirow[t]{2}{*}{ P-value } \\
\hline & & $\mathrm{P}$-value & Pseudo-F value & & & \\
\hline \multirow[t]{10}{*}{ Bacterial 16S } & Horizon position & $<0.0002$ & 3.507 & 11.7 & $\mathrm{H} 1$ vs $\mathrm{H} 2$ & $<0.01$ \\
\hline & & & & & $\mathrm{H} 1$ vs $\mathrm{H} 3$ & $<0.0001$ \\
\hline & & & & & $\mathrm{H} 2$ vs $\mathrm{H} 3$ & $<0.17$ \\
\hline & Aggregate-size fraction & $<0.0001$ & 6.137 & 19.09 & LM vs MAC & $<0.36$ \\
\hline & & & & & LM vs MIC & $<0.34$ \\
\hline & & & & & LM vs SC & $<0.0001$ \\
\hline & & & & & MAC vs MIC & $<0.14$ \\
\hline & & & & & MAC vs SC & $<0.0001$ \\
\hline & & & & & MIC vs SC & $<0.0001$ \\
\hline & Interaction & 0.007 & 1.381 & & & \\
\hline \multirow[t]{10}{*}{ Fungal ITS } & Horizon position & $<0.0001$ & 3.193 & 16.25 & $\mathrm{H} 1$ vs $\mathrm{H} 2$ & $<0.03$ \\
\hline & & & & & $\mathrm{H} 1$ vs $\mathrm{H} 3$ & $<0.03$ \\
\hline & & & & & $\mathrm{H} 2$ vs $\mathrm{H} 3$ & $<0.048$ \\
\hline & Aggregate-size fraction & $<0.0001$ & 2.93 & 17.82 & LM vs MAC & $<0.69$ \\
\hline & & & & & LM vs MIC & $<0.98$ \\
\hline & & & & & LM vs SC & $<0.0001$ \\
\hline & & & & & MAC vs MIC & $<0.42$ \\
\hline & & & & & MAC vs SC & $<0.0001$ \\
\hline & & & & & MIC vs SC & $<0.0001$ \\
\hline & Interaction & 0.626 & 0.925 & & & \\
\hline
\end{tabular}

Table 2

The effect of aggregate size fraction on bacterial 16S rRNA and fungal internal transcribed spacer (ITS) region based community composition within the individual horizon positions. Statistical significance P $<0.05$. *Large macroaggregate ITS PCR amplicons were not obtained in horizon 3 (H3).

\begin{tabular}{|c|c|c|c|c|c|}
\hline \multirow[t]{2}{*}{ Community } & \multirow{2}{*}{$\begin{array}{l}\text { Horizon } \\
\text { position }\end{array}$} & \multicolumn{2}{|c|}{ Main effect } & \multirow[t]{2}{*}{ Pairwise } & \multirow[t]{2}{*}{$\mathrm{P}$-value } \\
\hline & & P-value & $\begin{array}{l}\text { Pseudo-F } \\
\text { value }\end{array}$ & & \\
\hline \multirow[t]{13}{*}{ Bacterial 16S } & $\mathrm{H} 1$ & $<0.001$ & 7.252 & LM vs MAC & 0.89 \\
\hline & & & & LM vs MIC & 0.49 \\
\hline & & & & LM vs SC & $<0.001$ \\
\hline & & & & MAC vs MIC & 0.15 \\
\hline & & & & MAC vs SC & $<0.001$ \\
\hline & & & & MIC vs SC & $<0.001$ \\
\hline & $\mathrm{H} 2$ & 0.008 & 1.954 & LM vs MAC & 0.37 \\
\hline & & & & LM vs MIC & 0.12 \\
\hline & & & & LM vs SC & 0.046 \\
\hline & & & & MAC vs MIC & 0.21 \\
\hline & & & & MAC vs SC & $<0.01$ \\
\hline & & & & MIC vs SC & $<0.01$ \\
\hline & H3 & 0.341 & 1.116 & & \\
\hline \multirow[t]{15}{*}{ Fungal ITS } & $\mathrm{H} 1$ & $<0.001$ & 3.014 & LM vs MAC & 0.58 \\
\hline & & & & LM vs MIC & 0.996 \\
\hline & & & & LM vs SC & $<0.001$ \\
\hline & & & & MAC vs MIC & 0.7 \\
\hline & & & & MAC vs SC & $<0.001$ \\
\hline & & & & MIC vs SC & $<0.001$ \\
\hline & $\mathrm{H} 2$ & 0.025 & 1.629 & LM vs MAC & 0.67 \\
\hline & & & & LM vs MIC & 0.86 \\
\hline & & & & LM vs SC & 0.02 \\
\hline & & & & MAC vs MIC & 0.81 \\
\hline & & & & MAC vs SC & 0.01 \\
\hline & & & & MIC vs SC & 0.02 \\
\hline & $\mathrm{H} 3^{*}$ & 0.039 & 1.698 & MAC vs MIC & 0.28 \\
\hline & & & & MAC vs SC & 0.07 \\
\hline & & & & MIC vs SC & 0.03 \\
\hline
\end{tabular}

positions analysed together, however, the SC fraction harboured a distinct bacterial and fungal community structure when compared to the LM, MAC, and MIC fractions.

Aggregate stratification will result in heterogeneity in the distribution of $\mathrm{O}_{2}$, water, SOC and solutes in the soil matrix. These will differentially impact on certain microbial taxa and therefore affect community composition (Davinic et al., 2012; Ruamps et al., 2013). Bacterial cells have been shown to adhere to clay particles (Mueller, 2015) and also produce a polysaccharide secretion which penetrates the adjacent clay pores and forms polymeric bridges between clay particles. This process has been suggested as both an important mechanism for aggregate formation as well as SOC storage (Alimova et al., 2009; Denef and Six, 2005; Mueller, 2015). Additionally, it has also been proposed that that micro-porosity, such as that associated with SC, provides a safe environment for bacteria avoiding predation by as the likes of bacterivorous nematodes (Heijnen and van Veen, 1991). This often results in an increase in bacterial biomass in the SC fraction compared to larger fractions (Sessitsch et al., 2001).

Using the NGS technique, we also observed an effect of aggregate size on the bacterial community, agreeing with the T-RFLP data, though the specificities of this effect did differ between techniques. In H1, the relative abundance of the Firmicutes declined in the MAC compared to the MIC fraction. This is likely due to increased predation within MAC. Despite being Gram-positive (which are believed to be less preferred by protozoa due to their protective cell wall) the abundance of Firmicutes has been shown to decrease upon the addition of an amoeba predator (Rosenberg et al., 2009). While nematodes have been previously reported not to predate the most abundant bacteria present in soil (Ladygina et al., 2009), the tortuosity of the inner MAC fraction may allow the lesser abundant bacteria to escape predation by occupying niches inaccessible to the bacterivorous predators (Heijnen et al., 1993). Furthermore, the Acidobacteria were found to be enriched in the MAC fraction compared to the MIC, which concurs with the study from Mummey and Stahl (2004). While the extent of the Firmicutes was a surprise, it is not without precedent in grassland soils (Felske et al., 1998; Felske et al., 2000).

The MIC fraction, in contrast, is characterized by a low predation pressure (Ranjard and Richaume, 2001). Bacterivorous predation is known to be a major driver in the community structure of the Acidobacteria (Naether et al., 2012). Additionally, studies have demonstrated that the MIC represents an operationally defined microenvironment for the soil microbiota (Kong et al., 2011; Poly et al., 2001). While the inner MIC microhabitat has been described as a growth-limiting environment due to limited $\mathrm{O}_{2}$ permeability (Mummey et al., 2006), it does have a relatively stable water potential, and has restricted access for external toxic elements (Poly et al., 2001). 
Table 3

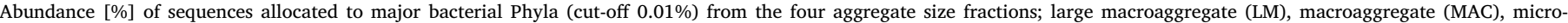

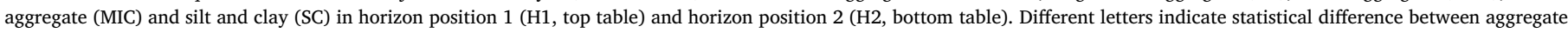
size fractions $(\mathrm{P}<0.05)$.

\begin{tabular}{|c|c|c|c|c|c|c|c|c|}
\hline \multirow[t]{2}{*}{ Phylum } & \multicolumn{2}{|l|}{ LM } & \multicolumn{2}{|l|}{ MAC } & \multicolumn{2}{|l|}{ MIC } & \multicolumn{2}{|l|}{ SC } \\
\hline & Avg. & \pm & Avg. & \pm & Avg. & \pm & Avg. & \pm \\
\hline \multicolumn{9}{|l|}{$H 1$} \\
\hline Acidobacteria & $2.715^{\mathrm{a}}$ & 5.921 & $8.255^{\mathrm{b}}$ & 7.069 & $0.373^{\mathrm{a}}$ & 0.273 & $4.248^{\mathrm{ab}}$ & 5.786 \\
\hline Actinobacteria & $3.635^{\mathrm{a}}$ & 4.360 & $6.435^{\mathrm{a}}$ & 4.861 & $1.891^{\mathrm{a}}$ & 1.371 & $5.824^{\mathrm{a}}$ & 6.090 \\
\hline Bacteroidetes & $0.189^{\mathrm{a}}$ & 0.291 & $0.416^{\mathrm{a}}$ & 0.367 & $0.039^{\mathrm{a}}$ & 0.028 & $0.432^{\mathrm{a}}$ & 0.628 \\
\hline Chlamydiae & $0.065^{\mathrm{ab}}$ & 0.063 & $0.199^{\mathrm{b}}$ & 0.162 & $0.020^{\mathrm{a}}$ & 0.013 & $0.090^{\mathrm{ab}}$ & 0.132 \\
\hline Chloroflexi & $0.657^{\mathrm{a}}$ & 1.366 & $1.473^{\mathrm{a}}$ & 2.283 & $0.192^{\mathrm{a}}$ & 0.214 & $1.239^{\mathrm{a}}$ & 1.673 \\
\hline Firmicutes & $70.900^{\mathrm{ab}}$ & 30.282 & $44.266^{\mathrm{b}}$ & 36.628 & $80.537^{a}$ & 16.014 & $64.199^{\mathrm{ab}}$ & 36.683 \\
\hline Gemmatimonadetes & $0.185^{\mathrm{a}}$ & 0.211 & $0.500^{\mathrm{a}}$ & 0.412 & $0.236^{\mathrm{a}}$ & 0.328 & $0.265^{\mathrm{a}}$ & 0.244 \\
\hline Nitrospira & $0.064^{\mathrm{a}}$ & 0.137 & $0.178^{\mathrm{a}}$ & 0.263 & $0.001^{\mathrm{a}}$ & 0.001 & $0.143^{\mathrm{a}}$ & 0.257 \\
\hline OP10 & $0.015^{\mathrm{a}}$ & 0.016 & $0.072^{\mathrm{a}}$ & 0.114 & $0.015^{\mathrm{a}}$ & 0.018 & $0.038^{\mathrm{a}}$ & 0.062 \\
\hline Planctomycetes & $1.041^{\mathrm{a}}$ & 1.909 & $3.212^{\mathrm{a}}$ & 2.814 & $0.717^{\mathrm{a}}$ & 0.444 & $1.884^{\mathrm{a}}$ & 1.967 \\
\hline Proteobacteria & $7.736^{\mathrm{a}}$ & 7.091 & $12.072^{\mathrm{a}}$ & 9.095 & $10.947^{\mathrm{a}}$ & 18.598 & $7.518^{\mathrm{a}}$ & 7.816 \\
\hline Unclassified & $11.019^{\mathrm{a}}$ & 10.166 & $18.456^{\mathrm{a}}$ & 10.687 & $4.215^{\mathrm{a}}$ & 4.417 & $11.117^{\mathrm{a}}$ & 10.000 \\
\hline Unclassified_bacteria & $0.016^{\mathrm{ab}}$ & 0.014 & $0.035^{\mathrm{a}}$ & 0.030 & $0.005^{\mathrm{b}}$ & 0.006 & $0.022^{\mathrm{ab}}$ & 0.033 \\
\hline Verrucomicrobia & $1.581^{\mathrm{a}}$ & 3.286 & $4.234^{\mathrm{a}}$ & 3.850 & $0.799^{\mathrm{a}}$ & 0.661 & $2.760^{\mathrm{a}}$ & 3.410 \\
\hline WS3 & $0.176^{\mathrm{a}}$ & 0.435 & $0.188^{\mathrm{a}}$ & 0.286 & $0.002^{\mathrm{a}}$ & 0.002 & $0.197^{\mathrm{a}}$ & 0.370 \\
\hline \multicolumn{9}{|l|}{ H2 } \\
\hline Acidobacteria & $0.364^{\mathrm{ab}}$ & 0.142 & $0.144^{\mathrm{a}}$ & 0.245 & $0.559^{\mathrm{ab}}$ & 0.480 & $1.705^{\mathrm{b}}$ & 2.683 \\
\hline Actinobacteria & $1.815^{\mathrm{ab}}$ & 1.043 & $0.834^{\mathrm{a}}$ & 1.222 & $2.787^{\mathrm{b}}$ & 1.416 & $5.273^{\mathrm{b}}$ & 4.317 \\
\hline Bacteroidetes & $0.015^{\mathrm{ab}}$ & 0.009 & $0.006^{\mathrm{a}}$ & 0.005 & $0.039^{\mathrm{ab}}$ & 0.034 & $0.199^{\mathrm{b}}$ & 0.465 \\
\hline Chlamydiae & $0.011^{\mathrm{c}}$ & 0.008 & $0.006^{\mathrm{ac}}$ & 0.008 & $0.081^{\mathrm{b}}$ & 0.069 & $0.034^{\mathrm{bc}}$ & 0.019 \\
\hline Chloroflexi & $0.142^{\mathrm{a}}$ & 0.107 & $0.091^{\mathrm{a}}$ & 0.183 & $0.169^{\mathrm{a}}$ & 0.149 & $0.674^{\mathrm{a}}$ & 1.008 \\
\hline Firmicutes & $87.104^{\mathrm{a}}$ & 4.052 & $82.288^{\mathrm{a}}$ & 18.808 & $73.277^{\mathrm{a}}$ & 17.319 & $72.240^{\mathrm{a}}$ & 21.104 \\
\hline Gemmatimonadetes & $0.118^{\mathrm{a}}$ & 0.098 & $0.016^{\mathrm{a}}$ & 0.012 & $0.165^{\mathrm{a}}$ & 0.134 & $0.200^{\mathrm{a}}$ & 0.150 \\
\hline OP10 & $0.035^{\mathrm{a}}$ & 0.022 & $0.017^{\mathrm{a}}$ & 0.038 & $0.017^{\mathrm{a}}$ & 0.038 & $0.030^{\mathrm{a}}$ & 0.038 \\
\hline Planctomycetes & $0.882^{\mathrm{ab}}$ & 0.239 & $0.318^{\mathrm{a}}$ & 0.491 & $0.279^{\mathrm{ab}}$ & 0.147 & $2.039^{\mathrm{b}}$ & 2.815 \\
\hline Proteobacteria & $2.758^{\mathrm{a}}$ & 1.990 & $11.047^{\mathrm{a}}$ & 17.407 & $12.753^{\mathrm{a}}$ & 13.158 & $8.208^{\mathrm{a}}$ & 7.878 \\
\hline Unclassified & $6.046^{\mathrm{a}}$ & 4.669 & $4.954^{\mathrm{a}}$ & 4.739 & $9.416^{\mathrm{a}}$ & 8.754 & $6.884^{\mathrm{a}}$ & 4.608 \\
\hline Verrucomicrobia & $0.686^{\mathrm{a}}$ & 0.345 & $0.259^{\mathrm{a}}$ & 0.384 & $0.427^{\mathrm{a}}$ & 0.309 & $2.440^{\mathrm{a}}$ & 3.999 \\
\hline
\end{tabular}

The majority of bacterial OTUs from both taxonomic levels were shared among each of the four aggregate sizes. All of the unique OTUs had a very low abundance (all $<0.01 \%$ ). It has been previously suggested that the lesser abundant bacterial groups are more important at differentiating the bacterial community at the aggregate scale (Davinic et al., 2012), and that is indeed the case here. The majority of the 'unique' bacterial groups were found either exclusively within the SC or shared with the SC and one or more of the larger aggregates-sizes, likely derived from the silt and clay proportion within these aggregates. This is interesting in light of what was seen with the bacterial 16S rRNA TRFLP data, with both this and previous studies reporting a distinct bacterial (and fungal) community within the SC (Sessitsch et al., 2001), highlighting that the SC provides a distinct microhabitat influencing microbial community structure.

The Deferribacteres, exclusive to the SC fraction in H1, are characterized by their preference for anaerobic respiration (Alauzet and Jumas-Bilak, 2014). Some bacterial groups within the Spirochaetes (also found in exclusively in SC) are also reportedly anaerobic and have been implicated in the breakdown of complex organic polymers (Droge et al., 2006). Of the eight families unique to this fraction, only the Leptospiraceae and Methylophilaceae are not known to be anaerobic (or contain anaerobic genera) (Doronina et al., 2014; Picardeau, 2014). This suggests that many of the bacterial groups unique to SC may be physiologically adapted to deal with unique conditions of the SC microenvironment, characterized by highly protected SOC and limited $\mathrm{O}_{2}$ availability (Sexstone et al., 1985). These growth-limiting conditions may also be driving the changes in bacterial and fungal community composition as observed with the T-RFLP technique. In H2, more families were shared between MIC and SC than any of the other aggregate-sizes indicating that with increasing depth these two aggregates may become increasingly physicochemically similar. With the majority of bacterial groups being shared across all aggregate-sizes, these results indicate that the aggregate spectrum has a greater influence on relative bacterial abundance than on harbouring distinct bacterial groups.

There was a significant effect of horizon position on bacterial (as seen with both community profiling techniques employed) and fungal community composition (T-RFLP). Soil depth has previously been shown to be a strong driver of microbial community structure in grassland soils (Will et al., 2010). In comparison to the surface horizons, sub-soils (defined as soil $30 \mathrm{~cm}$ below the surface) are typically colder (at least during summer months) and have lower rates of gas exchange as the abundance of air-filled pores declines with soil depth, resulting in an increase of anoxic microsites (Barber et al., 2004; Ekelund et al., 2001). With increasing depth, the substrate available for the soil microbiota decreases as a high proportion of SOC becomes stabilized by metal ions and bound to mineral surfaces (von Lutzow et al., 2006). Furthermore, the SOC available at depth will be more inherently recalcitrant (i.e., a wider $\mathrm{C}: \mathrm{N}$ ratio) which may be more energetically expensive to metabolise (Kramer and Gleixner, 2008). Indeed, it has even been suggested that microbial community activity is so low in subsoils that even labile substrates may remain non-degraded for significant periods of time, as numerous studies have demonstrated that the sub-soil is rich in otherwise potentially enzymatically labile $\mathrm{C}$ compounds (Krull and Skjemstad, 2003; Lal et al., 2011; Liang and Balser, 2008; Xiang et al., 2008).

The significant interaction between aggregate size and horizon position seen in bacterial community composition using the two differing techniques indicates that horizon position is a strong determinant of bacterial community structure. The influence of horizon position on aggregate fraction sizes was only evident for the MAC fraction. The increase in the abundance of the Firmicutes in the MAC fraction in $\mathrm{H} 2$ is possibly a consequence of the decline in bacterivorous predators reducing predation pressure. Protozoan abundance has been shown to decline rapidly with soil depth, more so than bacteria (Ekelund et al., 

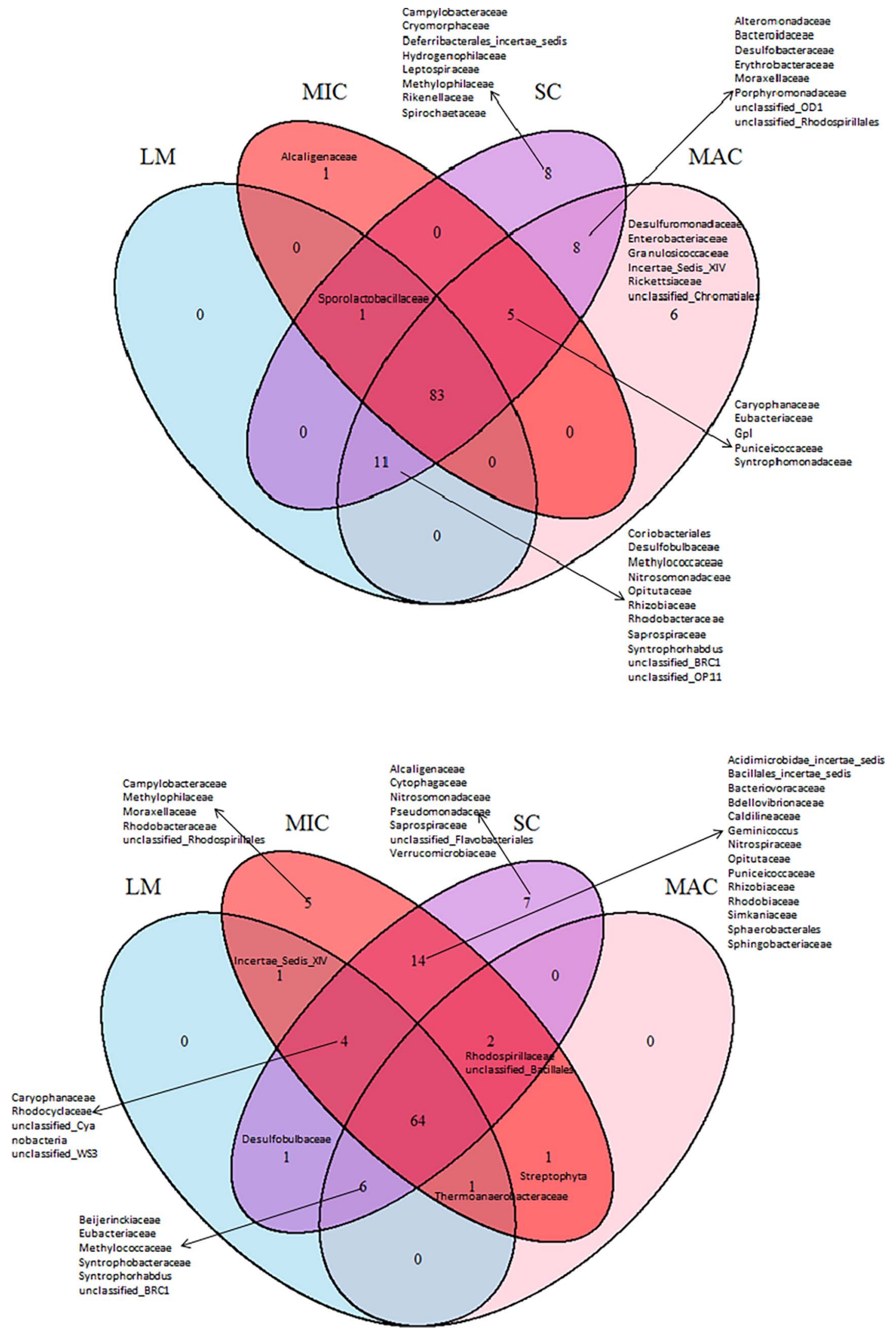

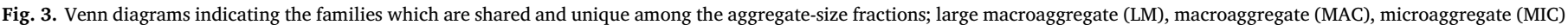
and silt and clay (SC) from horizon position 1 (H1, top) and horizon position 2 (H2, bottom). 
2001). The significant reduction in most of the other phyla in MAC between $\mathrm{H} 1$ and $\mathrm{H} 2$ indicates that they are being out-competed by the Firmicutes for resource acquisition and habitable niche space.

\section{Conclusion}

This study addressed the importance of aggregate size fraction and horizon position in determining patterns of microbial colonization, two aspects which have together been given relatively little attention in the literature. The strong effect of aggregate size on microbial community structure makes it clear that colonization patterns within the soil matrix are not homogenous. Thus, this highlights the need for microbial ecologists to focus efforts away from solely studying the bulk soil, as important configurations of microbial diversity are lost. Furthermore, the understanding the mechanisms behind this local scale structural organisation of the soil microbiome could have important implications for elucidating the mechanisms underlying microbial-led processes in soil, particularly $\mathrm{C}$ mineralization and sequestration.

\section{Acknowledgments}

This project was financed through the Teagasc Walsh Fellowship Scheme (Ref.: 2013017). Sampling and analysis was supported by the Irish Soil Information System project, managed by Teagasc (The Irish Agriculture and Food Development Authority) and co-funded by the Environmental Protection Agency (EPA) (2007-SCD-1-S1) of Ireland through their Science, Technology, Research and Innovation for the Environment (STRIVE) Programme, as part of the National Development Plan 2007-2013. We would also like to acknowledge funding received as part of the Agricultural GHG Research Initiative for Ireland (10/RD/AGRI-I/716). The authors would like to acknowledge the contribution of Dr. Brian Reidy for his invaluable assistance with the field work of this study. The authors also wish to declare no conflict of interest.

\section{Appendix A. Supplementary data}

Supplementary data associated with this article can be found, in the online version, at http://dx.doi.org/10.1016/j.apsoil.2018.02.023.

\section{References}

Alauzet, C., Jumas-Bilak, E., 2014. The phylum Deferribacteres and the genus Caldithrix. In: Rosenberg, E., DeLong, E.F., Lory, S., Stackebrandt, E., Thompson, F. (Eds.), The Prokaryotes: Other Major Lineages of Bacteria and the Archaea. Springer Berlin Heidelberg, Berlin, Heidelberg, pp. 595-611.

Alimova, A., Katz, A., Steiner, N., Rudolph, E., Wei, H., Steiner, J.C., Gottlieb, P., 2009. Bacteria-clay interaction: structural changes in smectite induced during biofilm formation. Clays Clay Miner. 57, 205-212.

Allison, S.D., Jastrow, J.D., 2006. Activities of extracellular enzymes in physically isolated fractions of restored grassland soils. Soil Biol. Biochem. 38, 3245-3256.

Alvarado, P., Manjón, J.L., 2009. Selection of enzymes for terminal restriction fragment length polymorphism analysis of fungal internally transcribed spacer sequences. Appl. Environ. Microbiol. 75, 4747-4752.

Apprill, A., McNally, S., Parsons, R., Weber, L., 2015. Minor revision to V4 region SSU rRNA 806R gene primer greatly increases detection of SAR11 bacterioplankton. Aquat. Microb. Ecol. 75, 129-137.

Barber, K.R., Leeds-Harrison, P.B., Lawson, C.S., Gowing, D.J.G., 2004. Soil aeration status in a lowland wet grassland. Hydrol. Process. 18, 329-341.

Bowles, T.M., Acosta-Martínez, V., Calderón, F., Jackson, L.E., 2014. Soil enzyme activities, microbial communities, and carbon and nitrogen availability in organic agroecosystems across an intensively-managed agricultural landscape. Soil Biol. Biochem. 68, 252-262.

Bronick, C.J., Lal, R., 2005. Soil structure and management: a review. Geoderma 124, $3-22$.

Clarke, K.R., Warwock, R.M., 2001. Changes in Marine Communities: An Approach to Statistical Analysis and Interpretation, 2nd ed. PRIMER-E, Plymouth.

Creamer, R., Simo, I., Reidy, B., Carvalho, J., Fealy, R., Hallett, S., Jones, R., Holden, A., Holden, N., Hannam, J., Massey, P., Mayr, T., McDonald, E., O’Rourke, S., Sills, P., T, Truckell, I., Zawadzka, J., Schulte, R., 2014. Irish Soil Information System (2007-SCD-1-S1) EPA STRIVE Programme 2007-2013. Synthesis Report.

Davinic, M., Fultz, L.M., Acosta-Martinez, V., Calderón, F.J., Cox, S.B., Dowd, S.E., Allen, V.G., Zak, J.C., Moore-Kucera, J., 2012. Pyrosequencing and mid-infrared spectroscopy reveal distinct aggregate stratification of soil bacterial communities and organic matter composition. Soil Biol. Biochem. 46, 63-72.

Denef, K., Six, J., 2005. Clay mineralogy determines the importance of biological versus abiotic processes for macroaggregate formation and stabilization. Eur. J. Soil Sci. 56, 469-479.

Doronina, N., Kaparullina, E., Trotsenko, Y., 2014. The family Methylophilaceae. In: Rosenberg, E., DeLong, E.F., Lory, S., Stackebrandt, E., Thompson, F. (Eds.), The Prokaryotes - Alphaproteobacteria and Betaproteobacteria. Springer Berlin Heidelberg, Berlin, Heidelberg, pp. 869-880.

Droge, S., Frohlich, J., Radek, R., Konig, H., 2006. Spirochaeta coccoides sp. nov., a novel coccoid spirochete from the hindgut of the termite Neotermes castaneus. Appl. Environ. Microbiol. 72, 392-397.

Ekelund, F., Rønn, R., Christensen, S., 2001. Distribution with depth of protozoa, bacteria and fungi in soil profiles from three Danish forest sites. Soil Biol. Biochem. 33, 475-481.

Elliott, E.T., 1986. Aggregate structure and carbon, nitrogen, and phosphorus in native and cultivated soils. Soil Sci. Soc. Am. J. 50, 627-633.

FAO, 2006. Guidelines for Soil Description. FAO, Rome, Italy, pp. 97.

Felske, A., Wolterink, A., Van Lis, R., Akkermans, A.D.L., 1998. Phylogeny of the main bacterial 16s rRNA sequences in Drentse A grassland soils (The Netherlands). Appl. Environ. Microbiol. 64, 871-879.

Felske, A., Wolterink, A., Van Lis, R., De Vos, W.M., Akkermans, A.D.L., 2000. Response of a soil bacterial community to a grassland succession as monitored by 16S rRNA levels of the prominent ribotypes. Appl. Environ. Microbiol. 66, 3998-4003.

Fox, A., Ikoyi, I., Creamer, R., Lanigan, G., Schmalenberger, A., 2017. Microbial community structure and function respond more strongly to temporal progression than to the application of slurry in an Irish grassland. Appl. Soil Ecol. 120, 97-104.

Gardes, M., Bruns, T.D., 1993. ITS primers with enhanced specificity for basidiomycetes application to the identification of mycorrhizae and rusts. Mol. Ecol. 2, 113-118.

Grundmann, G.L., 2004. Spatial scales of soil bacterial diversity - the size of a clone. FEMS Microbiol. Ecol. 48, 119-127.

Heijnen, C.E., Chenu, C., Robert, M., 1993. Micro-morphological studies on clay-amended and unamended loamy sand, relating survival of introduced bacteria and soil structure. Geoderma 56, 195-207.

Heijnen, C.E., van Veen, J.A., 1991. A determination of protective microhabitats for bacteria introduced into soil. FEMS Microbiol. Lett. 85, 73-80.

Kong, A.Y., Scow, K.M., Cordova-Kreylos, A.L., Holmes, W.E., Six, J., 2011. Microbial community composition and carbon cycling within soil microenvironments of conventional, low-input, and organic cropping systems. Soil Biol. Biochem. 43, 20-30.

Kramer, C., Gleixner, G., 2008. Soil organic matter in soil depth profiles: distinct carbon preferences of microbial groups during carbon transformation. Soil Biol. Biochem. 40, $425-433$.

Kravchenko, A.N., Negassa, W.C., Guber, A.K., Rivers, M.L., 2015. Protection of soil carbon within macro-aggregates depends on intra-aggregate pore characteristics. Sci. Rep. 5, 16261.

Krull, E.S., Skjemstad, J.O., 2003. $\delta 13 \mathrm{C}$ and $\delta 15 \mathrm{~N}$ profiles in 14C-dated Oxisol and Vertisols as a function of soil chemistry and mineralogy. Geoderma 112, 1-29.

Ladygina, N., Johansson, T., Canback, B., Tunlid, A., Hedlund, K., 2009. Diversity of bacteria associated with grassland soil nematodes of different feeding groups. FEMS Microbiol. Ecol. 69, 53-61.

Lal, R., Delgado, J.A., Groffman, P.M., Millar, N., Dell, C., Rotz, A., 2011. Management to mitigate and adapt to climate change. J. Soil Water Conserv. 66, 276-285.

Lane, D.J., 1991. Nucleic Acid Techniques in Bacterial Systematics. John Wiley \& Sons.

Liang, C., Balser, T.C., 2008. Preferential sequestration of microbial carbon in subsoils of a glacial-landscape toposequence, Dane County, WI, USA. Geoderma 148, 113-119.

Marx, M.C., Kandeler, E., Wood, M., Wermbter, N., Jarvis, S.C., 2005. Exploring the enzymatic landscape: distribution and kinetics of hydrolytic enzymes in soil particlesize fractions. Soil Biol. Biochem. 37, 35-48.

Massey, P., O'Connor, C., Sills, P., Fenelon, A., L., M.-F., Stone, D., Reidy, B., Creamer, R. 2014. Irish SIS Final Technical Report 7: Irish Soil Information System: Laboratory Standard Operating Procedures. Environmental Protection Agency, Ireland.

Mikha, M.M., Rice, C.W., 2004. Tillage and manure effects on soil and aggregate-associated carbon and nitrogen. Soil Sci. Soc. Am. J. 68, 809-816.

Mueller, B., 2015. Experimental interactions between clay minerals and bacteria: a review. Pedosphere 25, 799-810.

Mummey, D., Holben, W., Six, J., Stahl, P., 2006. Spatial stratification of soil bacterial populations in aggregates of diverse soils. Microb. Ecol. 51, 404-411.

Mummey, D.L., Stahl, P.D., 2004. Analysis of soil whole- and inner-microaggregate bacterial communities. Microb. Ecol. 48, 41-50.

Naether, A., Foesel, B.U., Naegele, V., Wust, P.K., Weinert, J., Bonkowski, M., Alt, F., Oelmann, Y., Polle, A., Lohaus, G., Gockel, S., Hemp, A., Kalko, E.K.V., Linsenmair, K.E., Pfeiffer, S., Renner, S., Schoning, I., Weisser, W.W., Wells, K., Fischer, M., Overmann, J., Friedrich, M.W., 2012. Environmental factors affect acidobacterial communities below the subgroup level in grassland and forest soils. Appl. Environ. Microbiol. 78, 7398-7406.

O'Brien, S.L., Gibbons, S.M., Owens, S.M., Hampton-Marcell, J., Johnston, E.R., Jastrow, J.D., Gilbert, J.A., Meyer, F., Antonopoulos, D.A., 2016. Spatial scale drives patterns in soil bacterial diversity. Environ. Microbiol. 18, 2039-2051.

Penny, C., Nadalig, T., Alioua, M., Gruffaz, C., Vuilleumier, S., Bringel, F., 2010. Coupling of denaturing high-performance liquid chromatography and terminal restriction fragment length polymorphism with precise fragment sizing for microbial community profiling and characterization. Appl. Environ. Microbiol. 76, 648-651.

Picardeau, M., 2014. The family Leptospiraceae. In: Rosenberg, E., DeLong, E.F., Lory, S. Stackebrandt, E., Thompson, F. (Eds.), The Prokaryotes: Other Major Lineages of Bacteria and the Archaea. Springer Berlin Heidelberg, Berlin, Heidelberg, pp. 711-729. 
Poly, F., Ranjard, L., Nazaret, S., Gourbiere, F., Monrozier, L.J., 2001. Comparison of nifH gene pools in soils and soil microenvironments with contrasting properties. Appl. Environ. Microbiol. 67, 2255-2262.

Ranjard, L., Poly, F., Combrisson, J., Richaume, A., Gourbiere, F., Thioulouse, J., Nazaret, S., 2000. Heterogeneous cell density and genetic structure of bacterial pools associated with various soil microenvironments as determined by enumeration and DNA fingerprinting approach (RISA). Microb. Ecol. 39, 263-272.

Ranjard, L., Richaume, A., 2001. Quantitative and qualitative microscale distribution of bacteria in soil. Res. Microbiol. 152, 707-716.

Raynaud, X., Nunan, N., 2014. Spatial ecology of bacteria at the microscale in soil. PLoS One 9, e87217.

Rillig, M.C., Mummey, D.L., 2006. Mycorrhizas and soil structure. New Phytol. 171, 41-53.

Rosenberg, K., Bertaux, J., Krome, K., Hartmann, A., Scheu, S., Bonkowski, M., 2009. Soil amoebae rapidly change bacterial community composition in the rhizosphere of Arabidopsis thaliana. ISME J. 3, 675-684.

Ruamps, L.S., Nunan, N., Pouteau, V., Leloup, J., Raynaud, X., Roy, V., Chenu, C., 2013. Regulation of soil organic C mineralisation at the pore scale. FEMS Microbiol. Ecol. $86,26-35$.

Schloss, P.D., Westcott, S.L., Ryabin, T., Hall, J.R., Hartmann, H., Hollister, E.B., Lesniewski, R.A., Oakley, B.B., Parks, D.H., Robinson, C.J., Sahl, J.W., Stres, B., Thallinger, G.G., Van Horn, D.J., Weber, C.F., 2009. Introducing mothur: opensource, platform-independent, community-supported software for describing and comparing microbial communities. Appl. Environ. Microbiol. 75, 7537-7541.

Sessitsch, A., Weilharter, A., Gerzabek, M.H., Kirchmann, H., Kandeler, E., 2001. Microbial population structures in soil particle size fractions of a long-term fertilizer field experiment. Appl. Environ. Microbiol. 67, 4215-4224.

Sexstone, A.J., Revsbech, N.P., Parkin, T.B., Tiedje, T.M., 1985. Direct measurement of oxygen profiles and denitrification rates in soil aggregates. Soil Sci. Soc. Am. J. 49, 645-651.

Six, J., Bossuyt, H., Degryze, S., Denef, K., 2004. A history of research on the link between (micro)aggregates, soil biota, and soil organic matter dynamics. Soil Till. Res. 79, $7-31$.

Six, J., Elliott, E.T., Paustian, K., Doran, J.W., 1998. Aggregation and soil organic matter accumulation in cultivated and native grassland soils. Soil Sci. Soc. Am. J. 62,
1367-1377.

Thomson, B.C., Tisserant, E., Plassart, P., Uroz, S., Griffiths, R.I., Hannula, S.E., Buée, M. Mougel, C., Ranjard, L., Van Veen, J.A., Martin, F., Bailey, M.J., Lemanceau, P., 2015. Soil conditions and land use intensification effects on soil microbial communities across a range of European field sites. Soil Biol. Biochem. 88, 403-413.

Tisdall, J.M., Oades, J.M., 1982. Organic matter and water-stable aggregates in soils. J. Soil Sci. 33, 141-163.

Torres-Sallan, G., Schulte, R.P.O., Lanigan, G.J., Byrne, K.A., Reidy, B., Simó, I., Six, J., Creamer, R.E., 2017. Clay illuviation provides a long-term sink for C sequestration in subsoils. Sci. Rep. 7, 45635.

vanGestel, M., Merckx, R., Vlassak, K., 1996. Spatial distribution of microbial biomass in microaggregates of a silty-loam soil and the relation with the resistance of microorganisms to soil drying. Soil Biol. Biochem. 28, 503-510.

von Lutzow, M., Kogel-Knabner, I., Ekschmitt, K., Matzner, E., Guggenberger, G., Marschner, B., Flessa, H., 2006. Stabilization of organic matter in temperate soils: mechanisms and their relevance under different soil conditions - a review. Eur. J. Soil Sci. 57, 426-445.

Vos, M., Wolf, A.B., Jennings, S.J., Kowalchuk, G.A., 2013. Micro-scale determinants of bacterial diversity in soil. FEMS Microbiol. Rev. 37, 936-954.

Wakelin, S.A., Macdonald, L.M., Rogers, S.L., Gregg, A.L., Bolger, T.P., Baldock, J.A., 2008. Habitat selective factors influencing the structural composition and functional capacity of microbial communities in agricultural soils. Soil Biol. Biochem. 40, 803-813.

White, T.J., Bruns, T., Lee, S., Taylor, J., 1990. Amplification and Direct Sequencing of Fungal Ribosomal RNA Genes for Phylogenetics. Academic Press, New York, USA.

Will, C., Thurmer, A., Wollherr, A., Nacke, H., Herold, N., Schrumpf, M., Gutknecht, J., Wubet, T., Buscot, F., Daniel, R., 2010. Horizon-specific bacterial community composition of german grassland soils, as revealed by pyrosequencing-based analysis of 16S rRNA genes. Appl. Environ. Microbiol. 76, 6751-6759.

WRB, I.W.G., 2006. World Reference Base for Soil Resources - a framework for international classification, correlation and communication. World Soil Resources Reports 103. FAO Rome, 128 pp., ISSN: 0532-0188.

Xiang, S.-R., Doyle, A., Holden, P.A., Schimel, J.P., 2008. Drying and rewetting effects on $\mathrm{C}$ and $\mathrm{N}$ mineralization and microbial activity in surface and subsurface California grassland soils. Soil Biol. Biochem. 40, 2281-2289. 